\title{
SELF-DEFEATING BEHAVIORS
}

EXPERIMENTAL RESEARCH, CLINICAL IMPRESSIONS, AND PRACTICAL IMPLICATIONS 


\title{
THE PLENUM SERIES IN \\ SOCIAL / CLINICAL PSYCHOLOGY
}

\author{
Series Editor: C. R. Snyder \\ University of Kansas \\ Lawrence, Kansas
}

\section{SELF-DEFEATING BEHAVIORS}

Experimental Research, Clinical Impressions, and Practical Implications Edited by Rebecca C. Curtis

A Continuation Order Plan is available for this series. A continuation order will bring delivery of each new volume immediately upon publication. Volumes are billed only upon actual shipment. For further information please contact the publisher. 


\title{
SELF-DEFEATING BEHAVIORS
}

\section{EXPERIMENTAL RESEARCH, CLINICAL IMPRESSIONS, AND PRACTICAL IMPLICATIONS}

\author{
EDITED BY \\ ReBeCCA C. Curtis
}

Adelphi University

Garden City, New York 


\section{Library of Congress Cataloging in Publication Data}

Self-defeating behaviors: experimental research, clinical impressions, and practical implications / edited by Rebecca C. Curtis.

p. $\quad \mathrm{cm} .-$ (The Plenum series in social/clinical psychology)

Includes bibliographies and index.

ISBN-13:978-1-4612-8080-4 e-ISBN-13:978-1-4613-0783-9

DOI: $10.1007 / 978-1-4613-0783-9$

1. Self-defeating behavior. 2. Self-fulfilling prophecy. 3. Fear of success. 4. Helplessness (Psychology) I. Curtis, Rebecca C. II. Series.

[DNLM: 1. Adaptation, Psychological. 2. Behavior. 3. Self Concept. BF 697 S4646] RC455.4.S43S45 1989

$158^{\prime} .1-\mathrm{dc} 20$

DNLM/DLC

89-8445

for Library of Congress $\quad$ CIP

Grateful acknowledgment is made for permission to reprint excerpts from the following material:

"The Black Riders and Other Lines" by Stephen Crane, from The Poems of Stephen Crane. Reprinted by permission of Cooper Square Publishers, Totowa, New Jersey.

Notes from the Underground by Fyodor Dostoevsky (R. E. Matlow, trans.). @ 1960 E. P. Dutton. Used by permission.

"Eveline" from Dubliners by James Joyce. Reprinted by permission of the Society of Authors.

"Psychopathology in monkeys" by H. H. Harlow and M. K. Harlow. From Experimental Psychopathology: Recent Research and Theory (H. D. Kimmel, ed.). (C) 1971 Academic Press. Used by permission.

Principles of Dynamic Psychiatry by J. H. Masserman. (C) 1946 W. B. Saunders Co. Used by permission.

"Self-handicapping and self-handicappers: A cognitive/attributional model of interpersonal selfprotective behavior" by S. Berglas. From Perspectives in Personality, Volume I (R. Hogan and W. H. Jones, eds.). ( 1985 JAI Press, Greenwich, Connecticut. Used by permission.

Rape: Victims of Crisis by A. Burgess and L. Holmstrom. (C) 1974 Brady. Used by permission of Appleton \& Lange.

Stress Response Systems by M. J. Horowitz. (c) 1976 Jason Aronson Inc. Used by permission.

(C) 1989 Plenum Press, New York

Sof tcover reprint of the hardcover lst edition 1989

A Division of Plenum Publishing Corporation

233 Spring Street, New York, N.Y. 10013

All rights reserved

No part of this book may be reproduced, stored in a retrieval system, or transmitted in any form or by any means, electronic, mechanical, photocopying, microfilming, recording, or otherwise, without written permission from the Publisher 
This volume is dedicated to those who have taken care of my children while I worked, especially Cellina Shaw, Joan Baker, Lorna Stiles, the Adelphi Child Activity Center, the Hunter-Lenox Creative Center, and, of course, my husband. I would also like to express my appreciation to my colleagues in psychology at Adelphi, especially Michael Leippe, Janice Steil, and George Stricker, for their encouragement; to my colleagues from other disciplines, especially Eugene Roth, for their contributions to my thinking; and to Eleanor Shaw and Pat Carey, for their assistance and support. 


\section{CONTRIBUTORS}

Craig A. Anderson, Department of Psychology, University of MissouriColumbia, Columbia, Missouri

Steven Berglas, McClean Hospital/Harvard Medical School, Belmont, Massachusetts

LISA M. Bossio, 4707 Fairway Drive, Rohnert Park, California

Donnah CANAVAN, Department of Psychology, Boston College, Chestnut Hill, Massachusetts

RebeCCA CURTIS, Department of Psychology, Adelphi University, Garden City, New York

JOHN M. DARLEY, Department of Psychology, Princeton University, Princeton, New Jersey

Norman T. FeATHER, Discipline of Psychology, The Finders University of South Australia, Bedford Park, South Australia

JoHn H. Fleming, Department of Psychology, University of Minnesota, Minneapolis, Minnesota

ALLEN J. FRANCES, Department of Psychiatry, New York Hospital, Cornell Medical Center, Payne Whitney Clinic, New York, New York

ARTHUR FRANKEL, Department of Psychology, Salve Regina - The Newport College, Newport, Rhode Island

RAYMOND L. Higgins, Department of Psychology, University of Kansas, Lawrence, Kansas

JAmes L. HiLTON, Department of Psychology, University of Michigan, Ann Arbor, Michigan

RonNie JanOfF-Bulman, Department of Psychology, University of Massachusetts-Amherst, Amherst, Massachusetts

Christopher Peterson, Department of Psychology, University of Michigan, Ann Arbor, Michigan

MORGAN P. Slusher, Department of Psychology, University of MissouriColumbia, Columbia, Missouri 
C. R. SNYDER, Department of Psychology, University of Kansas, Lawrence, Kansas

MEL L. SNYDER, Department of Psychology, Rutgers University, Newark, New Jersey

Timothy J. StRauman, Department of Psychology, University of WisconsinMadison, Madison, Wisconsin

CARol E. ThOMAS, Department of Psychology, University of MassachusettsAmherst, Amherst, Massachusetts

THOMAS A. WIDIGER, Department of Psychology, University of Kentucky, Lexington, Kentucky 


\title{
PREFACE
}

\author{
In the desert \\ I saw a creature, naked, bestial, \\ Who, squatting upon the ground, \\ Held his heart in his hands, \\ And ate of it. \\ I said: "Is it good, friend?" \\ "It is bitter-bitter," he answered: \\ But I like it \\ Because it is bitter, \\ And because it is my heart." \\ Stephen Crane \\ The Black Riders and Other Lines
}

\begin{abstract}
"It is the function of great art to purge and give meaning to human suffering," wrote Bernard Knox (1982, p. 149) in his introduction to Oedipus Rex. This is done by showing some causal connection between the hero's free will and his suffering, by bringing to the fore the interplay of the forces of destiny and human freedom. Knox states that Freud was wrong when he suggested that it was "the particular nature of the material" in Oedipus that makes the play so deeply moving, and not the contrast between destiny and human will. Knox believes that this play has an overpowering effect upon us, not only because we share the tendency of Oedipus to direct "our first sexual impulse towards our mother" and "our first murderous wish against our father," as Freud tells us, but also because the theological modification of the legend introduced by Sophocles calls into question the sacred beliefs of our time (Knox, 1982, pp. 133-137). It is the juxtaposition of the forces of fate and free will that creates the tension in Oedipus and in our most powerful dramas, as Knox points out. So it is also in the interplay of these forces that tension is created in all of our lives. It is in our behaviors emanating out of these moments of conflict that we create meaning in our lives, and that we create our identities. Feeling the pull of opposing forces, we perpetuate or transform our ways of acting and our way of being. In so doing we defeat or enhance our "self."
\end{abstract}


In Stephen Crane's poem we have the powerful image of a creature eating his heart out. In Oedipus, we have not only the image of a man who gouges his eyes out, but also a tragedy that begins in the belief in prophecies and in the belief in the power of forces greater than human ones to control a person's fate-a tragedy that might have been avoidable. Knox suggests that the "theological purpose" of Sophocles is to illumine the tragedy of the sacred belief of many people in his time in divine foreknowledge and preordination. If the belief in divine foreknowledge were eliminated, the rest of their religious worldview would also fall apart. "If the gods did not know the future, they did not know any more than man," Knox writes (p. 137). Prophecy was thus one of the great controversial questions of Sophocles' day.

In our century, the rise of knowledge in the social sciences, especially psychology, has brought again into question the accepted ideas regarding free will, destiny, and what happens when people attempt their best to overcome the forces bearing down upon the courses of their lives. Like Oedipus, when we see the truth about the plight we are condemned to suffer, in terror we may engage in behavior that makes us even more miserable or on reflection gain the strength to make our lives more meaningful and perhaps alleviate some of the conditions leading to the pain surrounding us.

In the drama Oedipus, there are two types of suffering: suffering imposed by the gods and suffering self-imposed by Oedipus. Although his destiny was predetermined, according to legend Oedipus might have chosen to escape the prophecy - and the realities of existence in a world of sexual and aggressive impulses - by becoming a priest. Instead, he chose to seek his fate. Had he and his parents not believed in the power of prophecies, they would not have engaged in the actions leading to Oedipus's ignorance of his own identity. Believing that he likely would be unable to control his impulses, Oedipus attempted to avoid what he feared most, thus bringing about the fate he dreaded. The only freedom remaining to Oedipus was to search for the truth. In this way he is responsible for what happened to him. Without this causal link between free will and suffering, the play would lose its meaning and its drama.

In this volume on Self-Defeating Behaviors, there are also two types of suffering. There is, first, suffering caused by behaviors difficult for people to avoid due to forces beyond their power, e.g., behaviors determined from an early age, and second, suffering caused by behaviors that are experienced as freely chosen in seeking to attain some desired goal such as a sense of identity.

As in Sophocles' day, we still wish to believe that the world is predictable and ordered and, simultaneously, that we have freedom of choice (that human agency can triumph over the forces of destiny). In Oedipus Rex, the tragedy was brought about by the forces of the gods, by belief in the enormous power of these forces, by ignorance, and by human action growing out of these beliefs and ignorance of what was most important in life-who one is and from whence one comes. Oedipus was a free agent responsible not for his ignorance but for his triumph over it. "But no person has the power to force the gods to act against his own desires," declares Oedipus. "May I then mention," states the chorus, "what 
is to me, the next best thing" (1l. 280-283). "Ignorance can be remedied," Knox notes (p. 151). Therein lies our greatest freedom.

As a graduate student, Morton Deutsch asked me to design an experiment in which the participants would destroy some asset they possessed if they were treated unfavorably or exploited in some way. I was unsuccessful in designing an experiment in which such self-destruction occurred in the laboratory, although I did manage to find conditions under which the participants would lower their performance and financial assets. The problem continued to intrigue me, however, embracing my interests in both social and abnormal psychology, as well as in literature and religion.

Exposed to the idea of "self-fulfilling prophecies" by Robert Merton, the research data I then collected with Mark Zanna on the "fear of success" was readily interpretable within the framework of the self-fulfilling prophecy (or expectancy confirmation processes). The diverse interests of Morton Deutsch, Mark Zanna, and Robert Merton coalesced within my research and graduate seminar on self-defeating behaviors. I would like to thank them for their contributions to my thinking. After completing my dissertation in the area of justice, I returned to work on "the choice to suffer." I would like to thank my students, Tony Mariano, Wayne Gersh, Pam Rietdorf, Diana Ronell, Paul Smith, Bob Moore, Steve Nyberg, Joe Ferrari, Kim Moore, Diane Felicio, Susan Gianone, and Paul Dobrin for their work on these "terrible things, and none done blindly now, all done with a will" (Sophocles, Oedipus Rex, 1l. 1359-1360 [translated by Robert Fagles]):

It was Apollo, Apollo my friends

Who brought into reality these pains upon pain, which are my misfortune.

But my own hand, itself, struck the blow;

I alone, no one else did it.

(Oedipus Rex, 11. 1329-1331)

I would also like to thank Tom Hefferman and Bill DeVito for their suggestions and Jim Fennelly for his translations of Oedipus Rex from the Greek.

New York, New York

Rebecca Curtis 


\section{CONTENTS}

Chapter 1

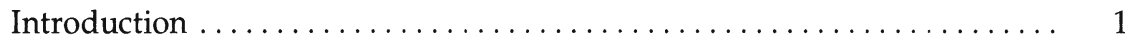

Rebecca Curtis

The Omote and Ura of Western Psychology................... 3

Overview of the Chapters in This Volume...................... 5

References....................................... 6

Part I. How Self-Defeating Behaviors DeVelop and Persist

\section{Chapter 2}

Belief Perseverance and Self-Defeating Behavior ................. 11

Morgan P. Slusher and Craig A. Anderson

Tenacious Beliefs and Self-Defeating Behaviors ................ 11

The Origins of Incorrect Beliefs . . . . . . . . . . . . . . . . . . . . . 15

The Perseverance of Beliefs ............................ 17

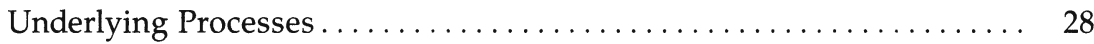

Implications for Belief Change $\ldots \ldots \ldots \ldots \ldots \ldots \ldots \ldots \ldots \ldots \ldots, 32$

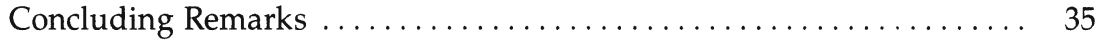

References...................................... 36

Chapter 3

Self-Fulfilling Prophecies and Self-Defeating Behavior.............. 41

James L. Hilton, John M. Darley, and John H. Fleming

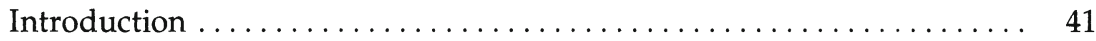

Toward a Theoretical Perspective on Self-Fulfilling Prophecies........ 44 
Implications for Self-Defeating Behavior $\ldots \ldots \ldots \ldots \ldots \ldots \ldots \ldots \ldots . \quad 55$

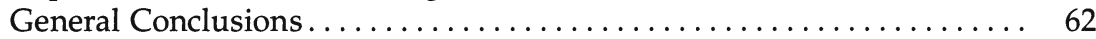

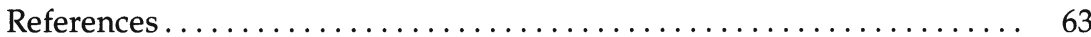

\section{Chapter 4}

Trying and Giving Up: Persistence and Lack of Persistence in

Failure Situations

Norman T. Feather

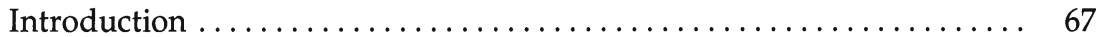

The Pathology of Low and High Expectations .............. 68

Persistence and Achievement Motivation................ 73

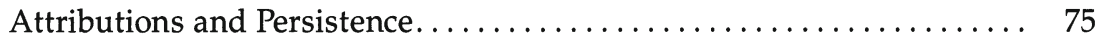

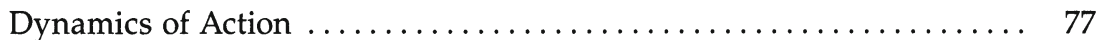

Action Control ......................................... 79

Attention and Self-Regulation $\ldots \ldots \ldots \ldots \ldots \ldots \ldots \ldots \ldots \ldots \ldots \ldots \ldots$

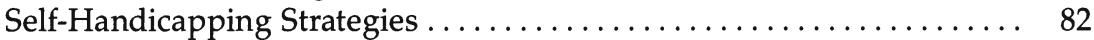

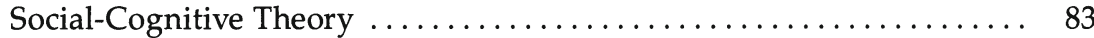

General Discussion . . . . . . . . . . . . . . . . . . . . . . . . . . . . . 87

References.................................. 90

PART II. SELF-DEFEATING RESPONSES TO THE

THREAT OF UNPLEASANT OUTCOMES

\section{Chapter 5}

Excuses Gone Awry: An Analysis of Self-Defeating Excuses . . . . . . . . 99

Raymond L. Higgins and C. R. Snyder

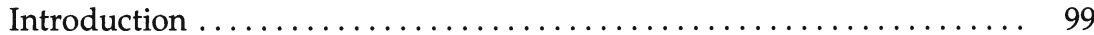

How Excuses Work ............................... 102

When Excuses Become Self-Defeating . . ................. 106

Why Self-Defeating Excuses? ......................... 120

References..................................... 126

\section{Chapter 6}

Making Things Harder for Yourself: Pride and Joy .............. 131

Mel L. Snyder and Arthur Frankel

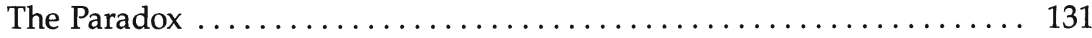

Making Things Harder for Yourself-Pride................. 132

Making Things Harder for Yourself-Joy. . . . . . . . . . . . . 141

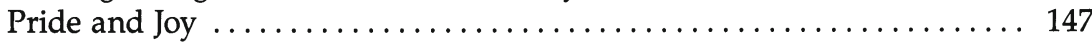

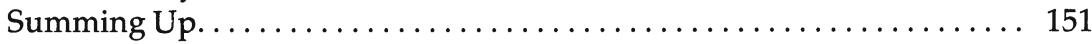

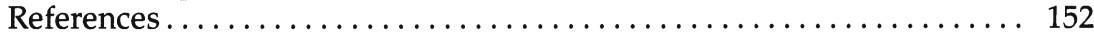




\section{Chapter 7}

Fear of Success ........................................ 159

Donnah Canavan

The Neurotic Fear of Success . . . . . . . . . . . . . . . . . . . . . . . . . 160

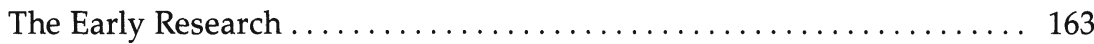

The Antecedents of Fear of Success . . . . . . . . . . . . . . . . . 167

Fear of Success and Fear of Failure $\ldots \ldots \ldots \ldots \ldots \ldots \ldots \ldots \ldots, 168$

Therapeutic Situations: Setups of Defeat for Success Fearers .......... 170

When Success Fearers Can and Cannot Succeed without

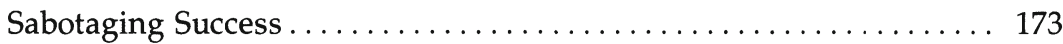

Fear of Success in Social Psychology . ..................... 177

Relationships among Fear of Success and Fear of Failure Measures .... 180

State of the Theory and Implications for Future Research . . . . . . . . 185

References...................................... 186

\section{Chapter 8}

Choosing to Suffer or to... ? Empirical Studies and Clinical Theories of Masochism....................................... 189

Rebecca Curtis

Suffering "the Slings and Arrows of Outrageous Fortune":

Experimental Studies of Masochism and "Choosing" to Suffer ...... 191

"The Undiscover'd Country": Clinical and Philosophical Ideas

Regarding Masochism.............................. 198

State of the Theory on Choosing to Suffer and Implications for

Future Research..................................... 204

Increasing the Likelihood of Choosing Not to Suffer Masochistically . . 207

Summary ....................................... 209

References....................................... 210

Chapter 9

Toward an Understanding of Self-Defeating Responses Following

Victimization..................................... 215

Ronnie Janoff-Bulman and Carol E. Thomas

Background Model of Reactions to Victimization.............. 216

Intrusive, Recurrent Thoughts ............................ 219

Self-Blame ....................................... 225

Negative Prior Assumptions .......................... 230

References....................................... 231 
Chapter 10

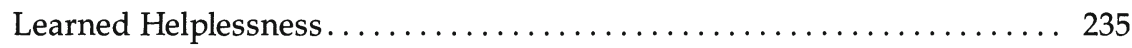

Christopher Peterson and Lisa M. Bossio

Two Decades of Learned Helplessness . . . . . . . . . . . . . . . 235

Criteria for Learned Helplessness . . . . . . . . . . . . . . . . . . . . 240

Evaluating Applications of Learned Helplessness . . . . . . . . . . . . 240

A Survey of Applications............................ 245

Conclusions ...................................... 252

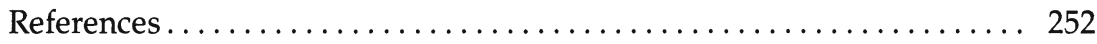

PARt III. When Situational Responses Become Personality Dispositions

Chapter 11

Self-Handicapping Behavior and the Self-Defeating Personality

Disorder: Toward a Refined Clinical Perspective .............. 261

Steven Berglas

Perspectives on Masochism. ...................... 263

Self-Esteem Protection: The Self-Handicapping Formulation . . . . . . . . 268

The Self-Defeating Personality Disorder . . . . . . . . . . . . . . . 272

Implications of the Proposed Trifurcation $\ldots \ldots \ldots \ldots \ldots \ldots \ldots \ldots \ldots$

Summary.................................. 283

Appendix: Diagnostic Criteria for Self-Handicapping Disorder. . . . . . . 284

References.................................. 285

\section{Chapter 12}

Controversies Concerning the Self-Defeating Personality Disorder. . . . . . 289

Thomas A. Widiger and Allen J. Frances

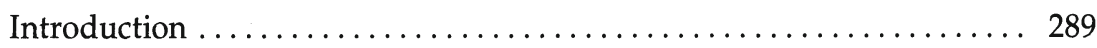

Historical Precedents . . . . . . . . . . . . . . . . . . . . . . . . . . . . . . . . . . 290

The DSM-III-R Criteria Set for SDPD . . . . . . . . . . . . . . . . . . . . . 292

Critiques ................................. 294

Discussion.................................. 297

Conclusions ....................................... 304

References...................................... 305 
Chapter 13

The Paradox of the Self: A Psychodynamic and Social-

Cognitive Integration $\ldots \ldots \ldots \ldots \ldots \ldots \ldots \ldots \ldots \ldots \ldots \ldots \ldots \ldots \ldots$

Timothy J. Strauman

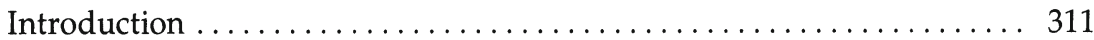

Psychodynamic Approaches: Masochism and the Three Harsh Masters. . 312

Evaluation of Psychodynamic Models of the Self . . . . . . . . . . 317

Social-Cognitive Approaches: Some Like It Cold. . . . . . . . . . . . . . . 319

Evaluation of Social-Cognitive Models of the Self . . . . . . . . . . . . . . 324

Unresolved Issues in the Paradox of the Self. . . . . . . . . . . . . . 325

Toward an Integrated Theory of Self-Representations. . . . . . . . . . . 328

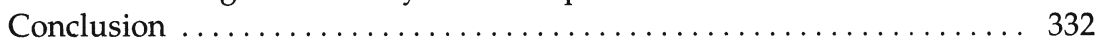

References................................. 333

\section{PART IV. CONCLUSIONS}

\section{Chapter 14}

Integration: Conditions underWhich Self-Defeating and Self-

Enhancing Behaviors Develop ...................... 343

Rebecca Curtis

Review of the Themes That Emerge in These Chapters . . . . . . . . . . 343

Conditions under Which Self-Defeating Behaviors Occur . . . . . . . . . . . 347

An Outline for an Integrated Model of Self-Defeating Behaviors. . . . . . . 350

Applications of the Integrated Model . . . . . . . . . . . . . . . . . 355

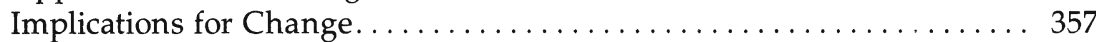

Conclusions ................................ 359

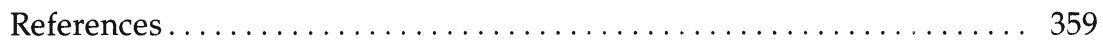

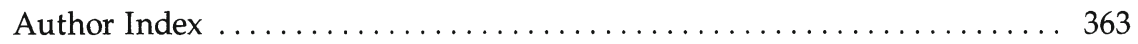

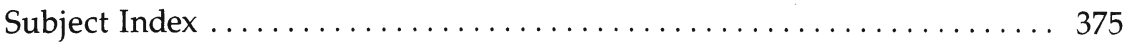

